\title{
The Lead and Lag Relationship Between Spot Market and Futures Market: Empirical Evidence From Vietnam
}

\author{
Nguyen Anh Phong ${ }^{1,2}$, Ho Thi Hong Minh ${ }^{1,2}$, Ngo Phu Thanh ${ }^{1,2} \&$ Tran Nguyen Thanh Son ${ }^{1,2}$ \\ ${ }^{1}$ Faculty of Finance and Banking, University of Economics and Law, Ho Chi Minh City, Vietnam \\ 2 Vietnam National University, Ho Chi Minh City, Vietnam \\ Correspondence: Nguyen Anh Phong, Ass. Prof (PhD), Faculty of Finance and Banking, University of Economics \\ and Law, Ho Chi Minh City, Vietnam.
}

Received: June 6, 2020

Accepted: August 15, 2020

Online Published: September 3, 2020

doi:10.5430/rwe.v11n5p192

URL: https://doi.org/10.5430/rwe.v11n5p192

\begin{abstract}
This study investigates the lead and lag relationship between Spot market and Futures market in Vietnam. In this study, we employ the data collected from stock-related database in Ho Chi Minh Stock Exchange and Ha Noi Stock Exchange. The data of daily closing prices of VN30 index (the spot price) and VN30F1M (the 1-month future price of VN30 index) are then collected. We apply various methods, namely: Granger causality test, Johansen co-integration test, Vector Error Correlation Model, Impulse Response Function and Variance Decomposition. The result of this paper is consistent with previous research. It finds strong evidence that Spot market leads Futures market in Vietnam stock market in both the short-run and long-run. Therefore, Spot market play a discovery role in which investors can obtain useful information from Spot market to improve their portfolio profit and minimize the risk. Besides, regulators can rely on this finding to come up with better policies and further develop Futures market.
\end{abstract}

Keywords: spot market, futures market, lead-lag relationship, Vietnam

JEL Classification: C58, E22, G11, G13

\section{Introduction}

Since the 1990s, the price discovery process is investigated by many studies around the world. The price discovery or the price mechanism is a method for investors to determine the actual price of the assets. Today, the derivatives have expanded rapidly and been trade in many markets. Therefore, the price discovery process of derivatives has received substantial attention in the scientific research community. There are many opinions about this greatest benefit of derivatives. This benefit comes from the asymmetric information among investors. Grossman (1989) indicated that if and only if the informed investors can get profit from their information, and some of that information is not transmitted for other investors, the Futures market tend to develop (Min \& Najand, 1999).

On the contrary, in a perfectly efficient market, every investor has received the same information. So, the price makes adjustments instantly and simultaneously to new information. So, there is no room for lead-lag relationships that exist between Spot and Futures market and arbitrage opportunities are impossible. Also, there is no way to beat the market because there are no undervalued or overvalued securities available. But, because of some reasons like differences in transaction cost, capital market microstructure effects, market structure, the significant lead-lag relationship between two markets still exists. Suppose the Futures market sometimes reacts faster to new information, regrading to economic events. If this lead-lag relationship actually exists, investors can use historical data to predict the future price in the Spot market. Thus, the Futures market plays an essential price discovery role. That means the Futures market may contain useful information about the subsequent Spot market. One market makes adjustments fully to new information faster than the other and carries lots of essential information. This is a great opportunity for traders to leverage arbitrage profit in the market.

Among other economies, Vietnam is one of the fastest emerging economies in the world. Vietnam's derivatives have just started official operations on August 10th 2017. After two years of operations, the derivatives market whose first product is VN30 index Futures has developed remarkably. There have been more than 36 million contracts reached on the market. In the first seven months of 2019, the volume of Futures contracts of shares indexes with the VN30-Index reached an average of nearly 100,000 contracts per session, an increase of 1.27 times compared to 2018 
and nearly 10 times higher than 2017. The volume of open interests (OI) increased 2.7 times from 8,077 contracts at the end of 2017 to 20,494 contracts on July 31, 2019. So far, the derivatives market has presented its role in effectively preventing risk and stabilizing investors' sentiment, especially when the stock market experienced strong fluctuations. There are four futures contracts traded with the VN30 index, including future contracts for the current month, the next month, the last 2 months of the next 2 quarters.

\begin{tabular}{ll}
\hline & VN30F1M Futures \\
\hline Maturity months & 1 month \\
\hline Trading unit & 1 contract \\
\hline Underlying asset & VN30 Index \\
\hline Trading collar & $+/-7 \%$ \\
\hline Daily settlement price & Regulated by VSD \\
\hline Settlement method & Cash settlement \\
\hline Tick size & Index point \\
\hline Position limit & Maximum number of index (VN30/HNX30) Futures in one \\
& account \\
& Professional securities Investors: 20,000 \\
& Institutional Investors: 10,000 \\
& Individual Investors: 5,000 \\
\hline
\end{tabular}

Because derivative securities have existed only two years ago, there are very few papers about Vietnam's derivatives market. Even though many studies investigate the lead-lag relationship between the Spot market and Futures market worldwide, little study research this relationship during 2017-2019 in Vietnam. The lead-lag relationship investigates whether the Spot market leads the Futures market, whether the Futures market leads the Spot market or whether the bi-directional feedback between the two markets exists. The lead-lag relationship illustrates how well the two markets are linked, and how fast one market reflects new information from the other. Therefore, this study tries to find the answer to two research questions. First, this paper strives to find the discovery role of Spot and Futures market. Secondly, this paper attempts to analyze the lead-lag relationship between two markets.

\section{Literature Review and Hypothesis}

Kawaller et al (1987) examined the lead-lag relationship between the S\&P 500 Index and S\&P 500 Futures of the 1984-1985 period. They used three-stage least-squares to estimate the lead and lag relationship with an estimate for expiration days of the S\&P 500 Futures compared with for days period to expiration. The outcomes suggested that Futures prices movements consistently lead index movements by twenty to forty-five minutes while movements in the index rarely affect Futures beyond one minute. Besides, Cheung \& Ng, (1990) also investigated the dynamics of both intraday price changes and volatilities in S\&P 500 Index and S\&P 500 Futures market. In their study, they performed causality on the correlation in price changes by using minute-to-minute transaction data on nearby S\&P 500 Futures contract. The causality test used in their context is interpreted as the Granger causality test. They showed that Futures prices lead Spot prices for the first 15 minutes of trading. However, the evidence was weak for Spot prices to have a substantial impact on future prices.

A complicated different methodology was employed in the research of Chan et al. (1991) used Bivariate GARCH Model. They also investigated the intraday relationship between returns and return volatility. Their data was five minutes of the S\&P 500 stock index and stock index Futures markets for the August 1984 to December 1989 period. Their outcomes were also different from previous researches. They indicated that a strong intermarket dependence in the volatility of the cash and Futures return. They also suggested that new market information disseminates in both the Spot and Futures markets and that both markets play important price discovery roles.

Nevertheless, K.Chan (1992) also investigated the intraday five-minute lead and lag relationship between return of Major Market cash index and the return of the Major Market Futures and S\&P 500 Futures in two sample periodAugust 1984 to June 1985 and January to September 1987. K.Chan (1992) indicated the existence of the lead-lag relationship between both markets. Instead of employing the Bivariate GARCH Model like the previous research, he 
used the regression model and found the strong evidence that there was an asymmetric lead-lag relationship between two markets.

Min \& Najand (1999) explored the ten-minute intraday possible lead and lag relationship in returns and volatilities between cash and Futures markets in Korea for the May 1996 to October 1996. By employed Simultaneous Equation Model (SEM) and Vector Autoregression (VAR), they found that the Futures market strongly leads the Spot market by as long as 30 minutes. Their result was consistent with previous studies conducted in other markets. As K.Chan (1992) hypothesis, the Futures market reflected wide information more rapidly than the Spot market.

Two years later, Brooks et al (2001) examined the lead and lag relationship between FTSE 100 - Index and index Futures prices for the June 1996 to June 1997 period by employing many time series models such as ECM model, VAR model. They indicated that the lagged changes in the Futures prices have existed which can help investors to predict the Spot price changes. The lead-lag relationship also has been examined in Greece by Floros and Vougas (2007). They employed Bivariate GARCH model and found that both FTSE/ASE-20 and FTSE/ASE Mid 40 Futures market play an important price discovery role, implying that the investors can obtain useful information from Futures market to predict Spot prices. They also indicated that the reason why Futures price leads Spot price included the fact that Futures markets have lower transaction costs and higher liquidity.

Two years later, Zakaria and Shamsuddin (2012) explored the lead and lag relationship and causality relationship between Spot index and Futures index for the January 2006 to November 2011 period. They used time series analysis such as unit root test to test the stationary properties of the series, Johansen cointegration, and Granger causality test. Vector Error Correction Model (VECM) also was used in their research. They indicated the existence of a long-run stable relationship between two markets. Meanwhile, the direction of causality was unidirectional from Spot market to Futures market. One of the most important results in their research is the Spot market leads the Futures market. According to Chan et al (1991), this result can be explained as spurious leads induced by infrequent trading of Futures contract.

Besides, The University of Southampton, Faculty of Business, (2012) investigated the potential lead-lag relationship between Spot and Futures market in three Southeast Asian Countries, namely Malaysia, Singapore, and Thailand. They used the data of daily closing Spot index prices and Futures index prices. Their methodology was the same as Zakaria \& Shamsuddin (2012). They also used Johansen cointegration test, Granger causality test, and VECM model. They provided strong evidence that Futures market returns lead Spot market returns in all three countries. Besides, there was a bidirectional causal effect between two markets in Malaysia whereas the only unidirectional causal effect in Singapore and Thailand by employing Granger causality test.

Dr. Naliniprava Tripathy (2014) explored the lead and lag relationship between Spot and Futures markets in Indian's derivative market by using the data of daily closing prices for the December 2005 to April 2013 period. By employing VAR model, VECM model, Variance Decomposition and Impulse Response Function, he suggested that Spot market leads Futures market and supports in price discovery process. Thus, investors can use Spot prices like a good indicator in predicting Futures prices to improve their portfolio.

Similarly, Rong-Yuan Qin and Ji-Hun Heo (2017) examined the lead-lag relationship the VKOSPI index futures and its underlying spot index and KOSPI index using daily data from September 17, 2014 to May 2017. They applied the unit root test, Johansen-Juselius cointegration test, Granger causality analysis, impulse response function analysis, and variance decomposition analysis The results of these analyses using level variables show that the VKOSPI spot market is more efficient than the futures market. However, there are no lead-lag relationship from VKOSPI futures or VKOSPI index to KOSPI index.

Moreover, Ren at al (2019) investigated the relationship among Futures, Options and Spot markets in Chinese Mainland, Hong Kong and the US. The dynamic evolution of lead-lag relationship revealed by a thermal optimal path (TOP) method whose essence is a nonparametric methodology. They found that Futures and Option markets except for Chinese Mainland had an effect on the Spot market and the Futures markets was used for price discovery. This research gives new and strong evidence that the lead-lag relationship varies in different markets, and with different market conditions. 
Table 1. Literature review

\begin{tabular}{|c|c|c|c|c|}
\hline Author & Country & Period & Market & Results \\
\hline $\begin{array}{l}\text { (Kawaller, Koch, \& Koch, } \\
1987 \text { ) }\end{array}$ & United States & During 1984 and 1985 & $\begin{array}{l}\text { S\&P } 500 \text { Futures } \\
\text {-S\&P } 500 \text { index }\end{array}$ & $\begin{array}{l}\text { Futures lead } \\
\text { Spot }\end{array}$ \\
\hline (Cheung \& Lilian, 1990) & United States & April 1982 to June 1987 & $\begin{array}{l}\text { S\&P } 500 \text { Futures } \\
\text {-S\&P } 500 \text { index }\end{array}$ & $\begin{array}{l}\text { Futures lead } \\
\text { Spot }\end{array}$ \\
\hline $\begin{array}{l}\text { (Chan, Chan, \& Karolyi, } \\
\text { 1991) }\end{array}$ & United States & $\begin{array}{l}\text { August } 1984 \text { to December } \\
1989\end{array}$ & $\begin{array}{l}\text { S\&P } 500 \text { Futures } \\
\text {-S\&P } 500 \text { index }\end{array}$ & $\begin{array}{l}\text { No lead-lag } \\
\text { relationship }\end{array}$ \\
\hline (K.Chan, 1992) & United States & $\begin{array}{l}\text { August } 1984 \text { to June } 1985 \\
\text { January to September } \\
1987\end{array}$ & Futures - Index Spot & $\begin{array}{l}\text { Futures lead } \\
\text { Spot }\end{array}$ \\
\hline (Min \& Najand, 1999) & Korea & $\begin{array}{l}\text { May } 1996 \text { to October } \\
1996\end{array}$ & Futures - Index Spot & $\begin{array}{l}\text { Futures lead } \\
\text { Spot }\end{array}$ \\
\hline $\begin{array}{l}\text { (Brooks, Rew, \& Ritson, } \\
\text { 2001) }\end{array}$ & United Kingdom & June 1996 to June 1997 & Futures - Index Spot & $\begin{array}{l}\text { Futures lead } \\
\text { Spot }\end{array}$ \\
\hline $\begin{array}{l}\text { (Roope \& Zurbruegg, } \\
\text { 2002) }\end{array}$ & $\begin{array}{l}\text { Taiwan and } \\
\text { Singapore }\end{array}$ & January 1999 to Jun 1999 & Futures - Index & $\begin{array}{l}\text { Bi-directional } \\
\text { relationship }\end{array}$ \\
\hline (Floros \& Vougas, 2007) & Greece & $\begin{array}{l}\text { August } 1999 \text { to August } \\
2001 \text { (FTSE/ASE-20) } \\
\text { January } 2000 \text { to August } \\
2001 \text { (FTSE/ASE MID } \\
40 \text { ) }\end{array}$ & Futures - Index Spot & $\begin{array}{l}\text { Futures lead } \\
\text { Spot }\end{array}$ \\
\hline $\begin{array}{l}\text { (Zakaria \& Shamsuddin, } \\
\text { 2012) }\end{array}$ & Malaysia & $\begin{array}{l}\text { January } 2006 \text { to } \\
\text { November } 2011\end{array}$ & Futures - Index Spot & $\begin{array}{l}\text { Spot lead } \\
\text { Futures }\end{array}$ \\
\hline $\begin{array}{l}\text { (The University of } \\
\text { Southamption, Faculty of } \\
\text { Business, 2012) }\end{array}$ & $\begin{array}{l}\text { Malaysia, } \\
\text { Thailand, and } \\
\text { Singapore }\end{array}$ & $\begin{array}{l}\text { October } 2006 \text { to October } \\
2012\end{array}$ & Futures - Index Spot & $\begin{array}{l}\text { Futures lead } \\
\text { Spot }\end{array}$ \\
\hline (Tripathy, 2014) & India & $\begin{array}{l}\text { December } 2005 \text { to April } \\
2013\end{array}$ & Futures - Index Spot & $\begin{array}{l}\text { Spot lead } \\
\text { Futures }\end{array}$ \\
\hline $\begin{array}{l}\text { (Rong-Yuan Qin \& Ji-Hun } \\
\text { Heo, 2017) }\end{array}$ & South Korea & $\begin{array}{l}\text { September } 2014 \text { to May } \\
2017\end{array}$ & $\begin{array}{l}\text { VKOSPI futures, } \\
\text { VKOSPI index and } \\
\text { KOSPI index }\end{array}$ & $\begin{array}{l}\text { No lead-lag } \\
\text { relationship }\end{array}$ \\
\hline Ren at al, 2019) & $\begin{array}{l}\text { Chinese } \\
\text { Mainland, Hong } \\
\text { Kong and the US }\end{array}$ & 2016 & $\begin{array}{l}\text { Futures, Options and } \\
\text { Spot markets }\end{array}$ & $\begin{array}{l}\text { Futures and } \\
\text { Option lead } \\
\text { Spot except for } \\
\text { Chinese } \\
\text { Mainland }\end{array}$ \\
\hline
\end{tabular}

The purpose of this study is to explore the lead-lag relationship between Spot market (VN30-Index) and Futures market (VN30-Index Futures contract). We investigate this problem on the side of the term of returns. Our paper inherits previous researches. Vietnam is the emerging economy like the sample of previous researches such as Zakaria and Shamsuddin (2012), Tripathy (2014). So, we interest in seeing if the information adjust is faster for Spot market than for Futures market. In simpler terms, we predict that the Spot prices lead Futures prices. We also predict the existence of long-run causality between two markets.

\section{Data and Methodology}

\subsection{Data Description}

The choice of data period

The data used in this paper are daily closing prices and Futures prices of the index of Vietnam. In particular, the data are retrieved from Vietstock, including the price index of VN30 and the Futures price of VN30F1M (VN30 Index 
Futures 1 month). There are many Futures index contract that was traded in Vietnam: VN30F1M, VN30F2M, VN30F1Q, VN30F1. Because the Futures contract VN30F1M is one of the most traded Futures contracts and the data of VN30 Futures index is not available, we concentrate on VN30F1M in this paper. In particular, the Hanoi Stock Exchange is young. Therefore, the data collected from the first day of trading VN30F1M to the end of the third quarter of 2019. The sample comprises 570 observations from August 18, 2017, to November 29, 2019.

Data frequency

In the literature, it is common that many studies used high-frequency data like hourly prices, thirty-minute prices, ten-minute prices or even minute-to-minute prices. Nevertheless, in this research, daily data will be employed. The main reason is that the Hanoi Stock Exchange is young, derivative trading is not as exciting as other emerging countries such as Thailand, Malaysia. Besides, the intraday data on VN30 index and its Futures index are not available. Therefore, in this paper, we use daily closing prices.

The logarithm of original data

Two-time series data that we obtain: VN30 index (Spot price) and VN30F1M (Futures price). As previous researches used the natural logarithms of the Spot index and Futures index such as Floros \& Vougas (2007) Zakaria \& Shamsuddin (2012), The University of Southampton, Faculty of Business (2012), Tripathy (2014), we also use the natural logarithms to obtain the Spot index returns and Futures index returns. The data set daily return are calculated of VN30 Index and VN30F1M by using the following formula

$$
R_{t}=\ln \left(\frac{P_{t}}{P_{t-1}}\right) * 100
$$

\subsection{Methodology}

In other to investigate the relationship between Spot prices and Futures prices, we use EViews 8 to run all the models. The methods used to analyze the time-series data are Unit Root test, Granger causality test, Johansen cointegration test. After that, if cointegration exists between two markets, two markets have a long-run relationship, VECM will be employed. Moreover, to examine the short-run relationship between two markets, we utilize the VAR model. Additional, Variance Decomposition and Impulse Response function tool will be applied too. Variance Decomposition is used to the variance of forecast errors while Impulse Response function allows us to test the dynamic effect of shock. However, AR tool and R-Squared will be used before Variance Decomposition and Impulse Response function to make sure that two tools are valid.

For Unit Root test, because many financial time-series have a unit root, i.e. the sample is not stationary and it is generally acknowledged that stock index series might not an exception. Therefore, before modeling any relationship, we have to test non-stationary (Tripathy, 2014). In this paper, we will use two methods to test for non-stationary, namely Augmented Dickey-Fuller (ADF), 1979, Phillip Perron (PP), 1988.

After that, we employ Granger causality test to examine the dynamic relationship between two markets. Many previous papers also use this test in their papers like Min \& Najand (1999), Brooks et al (2001), Floros \& Vougas (2007).

Like Granger causality test, Johansen cointegration test also was used in many previous papers such as Iihara Kato and Tokunaga (1996), Roope and Zurbruegg (2002), Judge and Reancharoen (2014). Johansen cointegration test will be employed to investigate the long-run relationship between Spot and Futures market. The most important advantage is that it does not only generate the single vectors but also generates the whole matrix of integrating ones; therefore this approach may enable more persistent estimation (The University of Southampton, Faculty of Business, 2012).

If the cointegration exists between spot and futures markets, in the sense that the existence of short-run and long-run relationship between two markets. Thus, we will use the VECM model to examine the dynamic relationship by estimating the parameters. If the cointegration does not exist between spot and futures markets, that means two markets just have a short-run relationship. Therefore, we will use VAR model. After that, Variance decomposition and Impulse response function will also be employed to analyze the time series.

\section{- Unit root test-Augmented Dickey-Fuller and Phillip Perron method}

Before any modeling or statistical test is employed, we have to ensure that the time-series which we used are stationary. There are many reasons why time series data have to be stationary. Firstly, if we use non-stationary data, the results of the regression will be spurious. Secondly, the assumption for asymptotic analysis will not be valid in 
the regression model (The University of Southampton, Faculty of Business, 2012). To test for non-stationary, in this paper, we will use two methods, namely Augmented Dickey-Fuller (ADF), 1979, Phillip Perron (PP), 1988 test. For Augmented Dickey-Fuller method and Phillip Perron method, the hypothesis HO is the series has a unit root. If the ADF t-statistic, PP t-statistic is smaller than the test critical value 1\%, 5\%, and $10 \%$ level, we reject $\mathrm{H} 0$. It makes sense that the time series data does not have a unit root problem.

\section{- $\quad$ Granger causality test}

There are many many methods to investigate the causality relationship between two markets such as ECM model,...But in this paper, we would like to use Granger causality test. According to previous researches, Granger causality test is the most popular method to investigate whether the existence of the lead and lag relationship between Spot index and Futures index. To name a few, Min \& Najand (1999), The University of Southampton, Faculty of Business (2012), Tripathy (2014) did Granger causality test in their papers.

Granger causality test is introduced by Clive W Granger. That is the statistic hypothesis test for determining whether one time-series is useful for forecasting another ("Granger Causality Test - an overview | ScienceDirect Topics," n.d.). The Granger causality test is more convenient than an order method in the sense that all variables are indigenous. That means we do not need to classify them as endogenous ones and exogenous ones. In summary, we will use Granger causality test to examine the dynamic relationship between Spot and Futures return.

\section{- Johansen cointegration test}

There are two main methods to test for cointegration, namely Engle and Granger test and Johansen cointegration test. The Johansen cointegration test is popular in previous empirical research. Zakaria \& Shamsuddin (2012), The University of Southampton, Faculty of Business (2012), Tripathy (2014) did indeed Johansen cointegration test in their researches.

The Engle and Granger test is intuitive, easy to perform but it has some limitations. Firstly, Augmented Dickey-Fuller is the second step, all the problems of Augmented Dickey-Fuller test are valid here as well, especially choosing the number of lags is a critical factor. Secondly, the test based on the assumption of one cointegration vector, captured by the cointegration regression, in the sense that it can ability to detect multiple vectors ("ECONOMETRIC WITH APPLICATIONS: Johansen Cointegration Test with EViews," n.d.). Thus, in this paper, we use Johansen cointegration test to examine the long-run relationship between Spot and Futures return.

\section{- Vector Error Correction Model (VECM)}

After Johansen cointegration test, if cointegration exists between two markets, VECM will be employed to investigate the long-run dynamic relationship between Spot market and Futures market. We follow the VECM that Tripathy (2014) used in his paper. The general form of the VECM is as follow:

$$
\begin{aligned}
& \Delta \mathrm{F}_{\mathrm{t}}=\alpha_{0}+\omega_{1}\left(\mathrm{~F}_{\mathrm{t}-1}-\theta \mathrm{S}_{\mathrm{t}-1}\right)+\sum_{\mathrm{i}=1}^{\mathrm{m}} \alpha_{\mathrm{i}} \Delta \mathrm{F}_{\mathrm{t}=\mathrm{i}}+\sum_{\mathrm{j}=\mathrm{i}}^{\mathrm{m}} \alpha_{\mathrm{j}} \Delta \mathrm{S}_{\mathrm{t}-\mathrm{j}}+\varepsilon_{1 \mathrm{t}} \\
& \Delta \mathrm{S}_{\mathrm{t}}=\beta_{0}+\omega_{2}\left(\mathrm{~F}_{\mathrm{t}-1}-\theta \mathrm{S}_{\mathrm{t}-1}\right)+\sum_{\mathrm{i}=1}^{\mathrm{m}} \beta_{\mathrm{i}} \Delta \mathrm{S}_{\mathrm{t}=\mathrm{i}}+\sum_{\mathrm{j}=\mathrm{i}}^{\mathrm{m}} \beta_{\mathrm{j}} \Delta \mathrm{F}_{\mathrm{t}-\mathrm{j}}+\varepsilon_{2 \mathrm{t}}
\end{aligned}
$$

$\Delta$ is the first difference operator; $\mathrm{F}_{\mathrm{t}-1}-\theta \mathrm{S}_{\mathrm{t}-1}$ is the error correction term determined from the level form estimate of the long-run relationship between Futures and Spot market. The lagged first difference $\left(\sum_{\mathrm{i}=1}^{\mathrm{m}} \alpha_{\mathrm{i}} \Delta \mathrm{F}_{\mathrm{t}=\mathrm{i}}+\right.$ $\left.\sum_{j=i}^{m} \alpha_{j} \Delta S_{t-j}\right)$ represents for the short-run effects. The equilibrium coefficient $(\omega)$ stands for the speed of adjustment coefficient in Spot and Futures market. $\omega$ is very important. Since the greater equilibrium coefficient indicates the higher speed of adjustment of the model from short-run to long-run. There is long-run causality running from Spot market to Futures market if the equilibrium coefficient $(\omega)$ is negative and statistically significant.

- Vector Autoregression model (VAR)

VAR model was firstly invented by Christopher Sim in 1980. The general form of VAR model is as follow:

$$
y_{t}=\delta+\varphi_{1} y_{t-1}+\cdots+\varphi_{p} y_{t-p}+u_{t}
$$


where $y_{t}=\left[\begin{array}{l}S t \\ F t\end{array}\right]$. And St stands for Spot Return, Rt stands for Futures Return

\section{- Impulse Response Function}

Impulse response identify responsiveness of the dependent variables (endogenous variables) when a shock is put into the error term such as $\varepsilon_{1 \mathrm{t}}$ and $\varepsilon_{2 \mathrm{t}}$ at the VECM model above. When a shock is put into the error term, example $\varepsilon_{1 \mathrm{t}}$, will bring the change in $\Delta \mathrm{F}_{\mathrm{t}}$. It will change the $\Delta \mathrm{F}_{\mathrm{t}=\mathrm{i}}$ and $\Delta \mathrm{S}_{\mathrm{t}-\mathrm{j}}$. It also affects the second equation. Therefore, we can give a shock to $\varepsilon_{1 \mathrm{t}}$ or $\varepsilon_{2 \mathrm{t}}$ of the above model to see it affects the whole VECM model. For calculating the impulse response function, the ordering of the variables is important. There are many methods that are given for ordering. In this paper, we have chosen Cholesky dof adjusted. Note that Impulse Response looks forward to a future period.

\section{- Variance Decomposition}

Instead of look forward to Futures period like Impulse response, variance decomposition allows us to see how current shock can be explained by the previous shock. If Spot market leads Futures market, the changes in Futures prices can be explained well by the changes in Spot prices. This is also an important tool when we use VECM model.

\section{Empirical Results}

\subsection{Descriptive Statistic}

Table 2. Descriptive statistic of daily spot return and futures return

\begin{tabular}{lll}
\hline & Spot Return & Futures Return \\
\hline Mean & 0.030871 & 0.031911 \\
\hline Median & 0.122212 & 0.068403 \\
\hline Std.Dev & 1.117315 & 1.299911 \\
\hline Skewness & -0.700398 & -0.494300 \\
\hline Kurtosis & 6.072505 & 5.680412 \\
\hline Jarque-Bera & 270.8097 & 193.8460 \\
\hline Probability & 0.0000 & 0.0000 \\
\hline
\end{tabular}

It appears from Table 2 that the mean of Spot Return is 0.030871 smaller than the mean of Futures Return 0.031911. The Std. Dev of Spot Return is also smaller than Std. Dev of Futures Return. It makes the sense that Futures Return is more volatile. Jarque-Bera is high in both of Spot market and Futures market. Additionally, the probability is 0.0000 for both Spot market and Futures market. So, we reject the hypothesis and return did not normal distribution. This is evidence that we should use Autoregression model.

Figure 1 below shows the downward and upward trend of Daily VN30 and VN30F1M. The graph also indicates that Futures Return is high volatile in comparison to Spot Return.

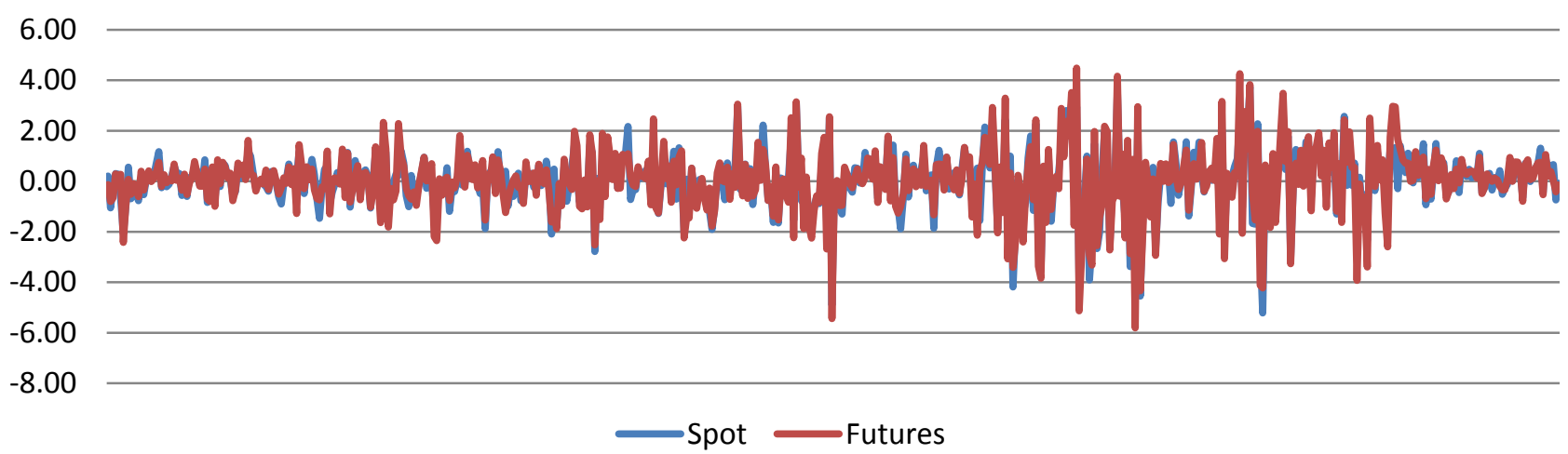

Figure 1. Daily spot return and futures return 


\subsection{Unit Root Test}

Table 3. Unit Root test by Augmented Dickey-Fuller test and Phillips-Perron test

\begin{tabular}{|c|c|c|c|c|}
\hline Variable & $\mathrm{ADF}$ & Probability & $\mathrm{PP}$ & Probability \\
\hline Spot Return & -14.70284 & 0.0000 & -23.79772 & 0.000 \\
\hline Futures Return & -14.61936 & 0.0000 & -26.32797 & 0.000 \\
\hline Critical Values & \multicolumn{2}{|c|}{$\mathrm{ADF}$} & \multicolumn{2}{|c|}{$\mathrm{PP}$} \\
\hline $1 \% \quad$ level & \multicolumn{2}{|c|}{-3.441634} & \multicolumn{2}{|c|}{-3.441613} \\
\hline $5 \% \quad$ level & \multicolumn{2}{|c|}{-2.866410} & \multicolumn{2}{|c|}{-2.866401} \\
\hline $10 \%$ level & \multicolumn{2}{|c|}{-2.569423} & \multicolumn{2}{|c|}{-2.569418} \\
\hline
\end{tabular}

H0: The series has a unit root

In this paper, we use the Augmented Dickey-Fuller (ADF) test and Phillips-Perron test to examine for the non-stationary. It is seen from Table 3 that both the Augmented Dickey-Fuller t-statistic and Phillips-Perron t-statistic are smaller than critical values at all levels $1 \%, 5 \%$, and $10 \%$. Thus, the null hypothesis is rejected. Spot Return and Futures Return do not have unit root and both of them are a stationary series at 1\%, 5\% and $10 \%$ significant levels. Therefore, the condition for stationary is met. Therefore, Granger causality test conducted later will have trustworthy results.

\subsection{Granger Causality Test}

Before Granger causality test, we have to determine the lag values. The lag value is chosen on the basis of LR, FPE, AIC criteria. It is seen from Table 4 that SC criteria and HQ criteria suggest the suitable lag is 2. But LR, FPE and AIC criteria indicate the suitable lag is 5 . Therefore, in this paper, we will use lag 5 based on LR, FPE and AIC criteria.

Table 4. Lag order selection

\begin{tabular}{ccccccc}
\hline Lag & LogL & LR & FPE & AIC & SC & HQ \\
\hline 0 & -1358.817 & NA & 0.434748 & 4.842767 & 4.858181 & 4.848785 \\
1 & -1332.184 & 52.98335 & 0.401104 & 4.762219 & 4.808463 & 4.780273 \\
2 & -1317.093 & 29.91202 & 0.385582 & 4.722752 & $4.799825^{*}$ & $4.752842^{*}$ \\
3 & -1312.784 & 8.510925 & 0.385159 & 4.721652 & 4.829554 & 4.763778 \\
4 & -1305.215 & 14.89666 & 0.380298 & 4.708949 & 4.847680 & 4.763111 \\
5 & -1299.432 & $11.33965^{*}$ & $0.377894^{*}$ & $4.702603^{*}$ & 4.872164 & 4.768802 \\
6 & -1296.453 & 5.820190 & 0.379272 & 4.706237 & 4.906627 & 4.784472 \\
7 & -1295.763 & 1.342580 & 0.383770 & 4.718017 & 4.949236 & 4.808288 \\
8 & -1293.018 & 5.322766 & 0.385493 & 4.722486 & 4.984534 & 4.824793 \\
\hline
\end{tabular}

After determining the lag values, we employ Granger causality test to investigate the lead and lag relationship between Spot and Futures market. At the significant of 5\%, if the probability is smaller than 5\%, the null hypothesis should be rejected. On the other hand, if the probability is greater than 5\%, we cannot reject the null hypothesis.

Table 5. Granger causality test

\begin{tabular}{lcc}
\hline \multicolumn{1}{c}{ Null hypothesis } & T-statistic & Probability \\
\hline SPOT does not Granger Cause FUTURES & 3.10259 & 0.0090 \\
\hline FUTURES does not Granger Cause SPOT & 1.46134 & 0.2007 \\
\hline
\end{tabular}


It appears from Table 5 that for the null hypothesis H0: SPOT does not Granger Cause FUTURES, the probability is 0.0090. Because probability is smaller than 5\% significant values, the null hypothesis should be rejected. In other words, it indicates that Spot does Granger Cause Futures. In the same way, for the null hypothesis H0: FUTURES does not Granger Cause SPOT, probability is 0.2007 . Since probability is greater than $5 \%$ significant values, we cannot reject the null hypothesis. In simpler terms, Futures does not Granger Cause Spot.

To summarize, Granger causality test indicates there is a unidirectional causality relationship between Spot and Futures market. Spot market leads Futures market. It is evident that Spot market contains important and useful information for the prediction of the Futures price. Furthermore, the news of Spot market impact on the Futures market and information flow from Spot to Futures market freely. Also, any change in Spot market causes the change in Futures market in the short-term. Therefore, investors can get information from Spot market and use it to make decisions with a rational strategy to minimize the risk in the market.

\subsection{Johansen Cointegration Test}

Table 6. Johansen cointegration test

\begin{tabular}{ccccc}
\hline $\begin{array}{c}\text { Max - Eigen } \\
\text { Statistic }\end{array}$ & 5\% Critical Value & Trace Statistic & $5 \%$ Critical Value & $\begin{array}{c}\text { Hypothesized No. of } \\
\text { CE(s) }\end{array}$ \\
\hline 154.4633 & 14.26460 & 242.0548 & 15.49471 & None $^{*}$ \\
\hline 87.59151 & 3.841466 & 87.59151 & 3.841466 & At most $1^{*}$ \\
\hline
\end{tabular}

Trace test indicated 2 cointegrating eqn(s) at the 0.05 level

*denotes rejection of the hypothesis at the 0.05 level

**MacKinnon-Haug-Michelis (1999) P-values

In Johansen cointegration test, the null hypothesis is there is no cointegration between two series. If the T-statistic value is greater than 5\% Critical Value, the null hypothesis should be rejected. There is a long-run relationship between two series.

The results of Johansen cointegration test are presented in Table 6. Two likelihood test statistic, Max-Eigen Statistic, and Trace-Statistic, are employed to determine the number of cointegration vector. It appears from Table 6 that both in term None and At most 1, Max-Eigen Statistic and Trace Statistic are greater than 5\% Critical Value. Therefore, Johansen cointegration test indicates that there is a long-run relationship between Spot and Futures market. It makes the sense that at least one market can be used to forecast the other market in the long-run. Also, in the long-run, both markets share common information.

\subsection{Vector Error Correction Model}

As we discuss, if the cointegration exists between Spot and Futures market, VECM model will be employed to investigate the dynamic short-run and long-run between Spot and Futures market. Appendix 1 presents the VECM's results. But, we have to test for the trusty of the VECM's results firstly. Figure 2 presents the AR Root Graph. It appears from Appendix 1 that R-Squared of both of two models is large. Besides, F-statistic is also significant. Additionally, it is seen from Figure 2 that all root lies inside the unit circle. Thus, we can rely on the VECM's results. 


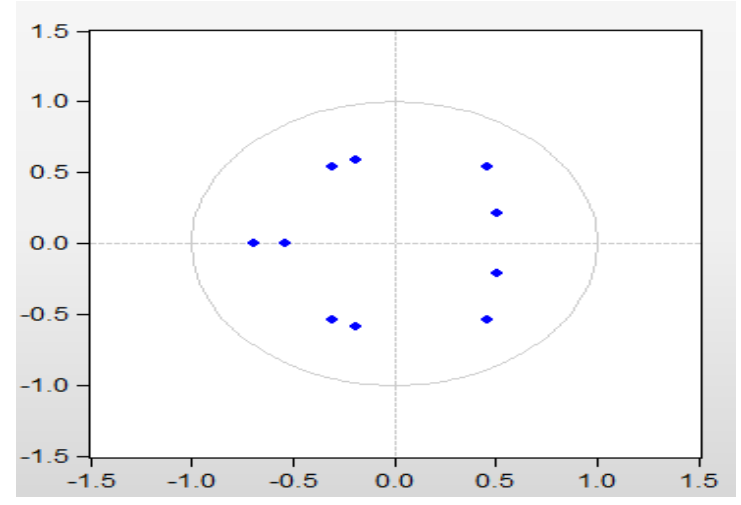

Figure 2. AR Root graph for VECM model

In the long-run, the coefficient of the error term (CointEq1) stands for the speed of adjustment towards a long-run equilibrium but it must be significant and negative. The CointEq1 is significant when it more than $1.96(5 \%$ of significant). Since the absolute value of (-4.224) is greater than 1.96, the CointEq1 is just statistically significant in the equation where Futures is the dependent variable. It makes the sense that Futures market are adjusting to re-established equilibrium condition during the next period. Since the coefficient of the error term is negative $(-1.558939)$ and statistically significant, there is a long-run causality running from Spot market to Futures market. In other words, in the long-run, Spot market leads Futures market.

In the short-run, we employ Wald-test to investigate the short-run causality between two markets. In the second equation where Spot market is dependent variable, it is seen that D(FUTURES(-1)), D(FUTURES(-2)), D(FUTURES(-3)), D(FUTURES(-4)) and D(FUTURES(-5)) is not statistically significant. Besides, based on the Granger causality test, there is only a unidirectional causality relationship between two markets. That causality relationship is Spot market leads Futures market. Therefore, without Wald-test, we can confirm that Futures does not lead Spot in the short-run.

On the other side, in first equation where Futures market is dependent variable, $\mathrm{D}(\mathrm{SPOT}(-1))$, $\mathrm{D}(\mathrm{SPOT}(-2))$ and $\mathrm{D}$ (SPOT(-3)) is significant. We can examine the causality short-run relationship between two markets by utilizing Wald-test to provide strong evidence to support Granger causality test. Firstly, we conduct Estimate Equation by Least Squares method which presents in Appendix 2. After that, we employ Wald-test. Table 7 presents Wald-test 's results. It appears from Appendix 2 that the short-run relationship between Spot market and Futures market is presented by $\mathrm{C}(7), \mathrm{C}(8), \mathrm{C}(9), \mathrm{C}(10)$ and $\mathrm{C}(11)$. If all of that does not equal zero and equal to each other, there is a short-run causality running from Spot market to Futures market. The null hypothesis is all of that equal to each other and equal zero. In order to examine this problem, we utilize Wald-test. Since probability is statistically significant, the null hypothesis should be rejected. Therefore, there is short-run causality running from Spot market to Futures market. In simpler terms, Spot market leads Futures market in the short-run. This result is consistent with the result of Granger causality test above. However, both Spot market and Futures market are not affected by its past values since almost coefficient short-run of Spot to Spot and Futures to Futures are not statistically significant.

Table 7. Wald-test result

\begin{tabular}{ccc}
\hline Test Statistical & Value & Probability \\
\hline Chi-Square & 24.09842 & 0.0001 \\
\hline
\end{tabular}


Response to Cholesky One S.D. Innovations
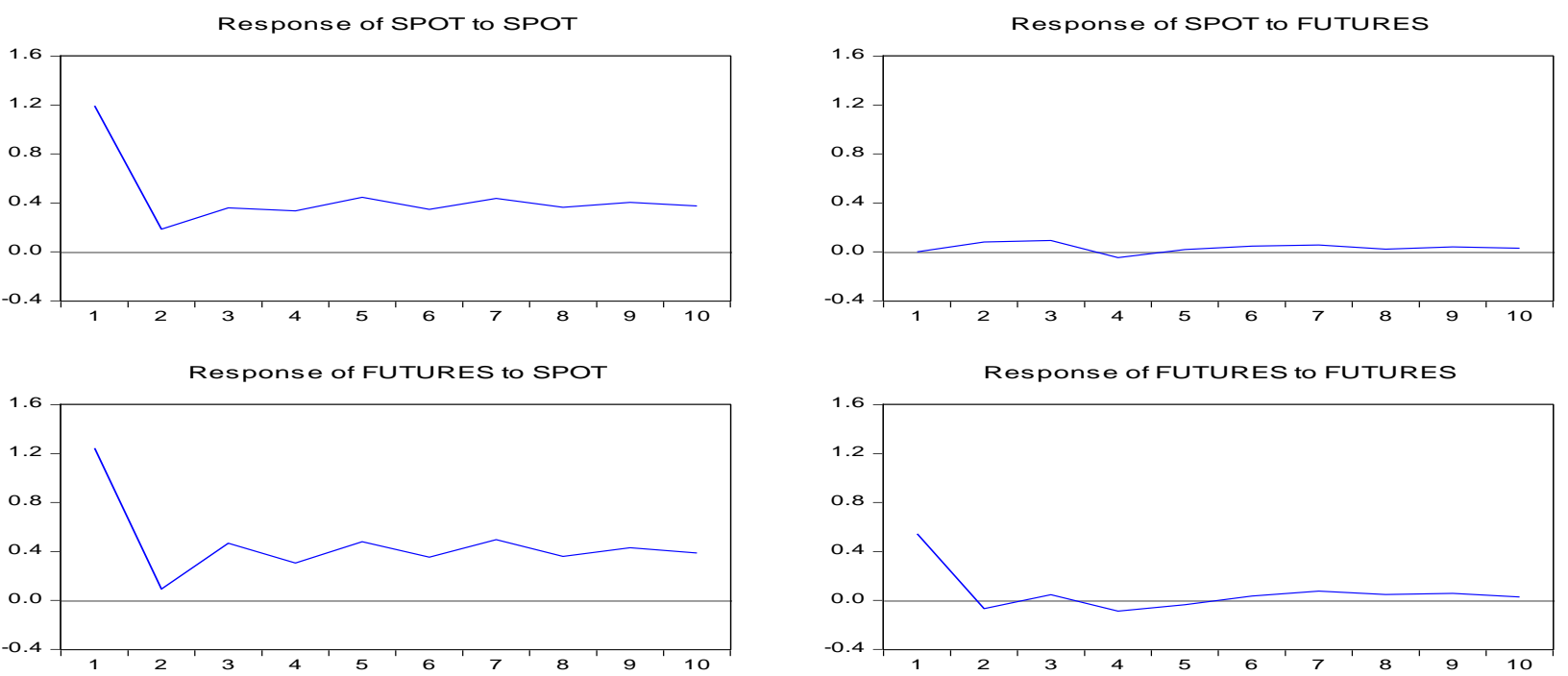

Figure 3. Impulse response function

The Impulse Response Function is conducted to investigate the dynamic effect caused by the VECM model when it received a shock. It appears from Figure 3 that when a shock is put into Spot market, it will decline on the first day then be stability during the next nine-day. That is similar to Futures market. It consists of the result of the short-run causality of VECM model. Both Spot market and Futures market are not affected by its past values. The other essential result when utilizing Impulse Response function is the response of Futures when Spot market has received a shock. As we can see on Figure 3, the Futures will drop significantly on the first day. Then, it will be high volatility. On the contrary, Spot market is not affected adversely by the Futures market's shock. It consists of results of the Granger test and VECM model since Futures market does not contain efficient information to predict Spot market.

\subsection{Variance Decomposition}

Table 8. Variance decomposition of spot

\begin{tabular}{cccc}
\hline $\begin{array}{c}\text { Variance } \\
\text { Decomposition of } \\
\text { SPOT: } \\
\text { Period }\end{array}$ & S.E. & & \\
& & & \\
& & & FUTURES \\
\hline 1 & 1.193611 & 100.0000 & 0.000000 \\
\hline 3 & 1.210495 & 99.55112 & 0.448878 \\
\hline 4 & 1.265987 & 99.05350 & 0.946504 \\
\hline 5 & 1.310175 & 98.98775 & 1.012254 \\
\hline 6 & 1.384076 & 99.07450 & 0.925504 \\
\hline 7 & 1.427531 & 99.02310 & 0.976902 \\
\hline 8 & 1.493955 & 98.96725 & 1.032749 \\
\hline 10 & 1.537831 & 99.00588 & 0.994117 \\
\hline & 1.590653 & 99.00449 & 0.995515 \\
\hline
\end{tabular}


Table 9. Variance decomposition of futures

\begin{tabular}{cccc}
\hline $\begin{array}{c}\text { Variance } \\
\text { Decomposition of } \\
\text { FUTURES: } \\
\text { Period }\end{array}$ & S.E. & SPOT & FUTURES \\
\hline 1 & 1.357678 & 83.95201 & 16.04799 \\
\hline 2 & 1.362516 & 83.81705 & 16.18295 \\
\hline 3 & 1.441199 & 85.42970 & 14.57030 \\
\hline 4 & 1.475756 & 85.75113 & 14.24887 \\
\hline 5 & 1.552133 & 87.06830 & 12.93170 \\
\hline 6 & 1.592371 & 87.66492 & 12.33508 \\
\hline 7 & 1.669881 & 88.57589 & 11.42411 \\
\hline 8 & 1.708876 & 89.01048 & 10.98952 \\
\hline 9 & 1.763224 & 89.57458 & 10.42542 \\
\hline 10 & 1.805456 & 90.03399 & 9.966012 \\
\hline
\end{tabular}

Variance Decomposition allows us to investigate how current shock can be explained by the previous shock. It is seen from Table 8 that ten-day ago of Futures market price shocks can explain just approximately $1 \%$ for current Spot market price shocks. That also means only $1 \%$ of its change in Futures market is attributed to Spot market. That also indicates that a very weak causality relationship running from Futures to spot. Thus, Futures does not have power to predict Spot. On the other side, it appears from Table 9 that Spot market prices shock attributes around 85\% to Futures market. Again, this result from Variance Decomposition consists of previous tool analysis. That is Spot market contain useful information and has strong power to predict Futures market.

\section{Conclusion}

This paper investigates the lead and lag relationship between spot and Futures market in Vietnam. The study has used the Augmented Dickey-Fuller test and Phillip-Perron test to examine the stationary of spot and Futures return. The result indicates that VN30 and VN30F1M are stationary at their level. The short-run causality relationship running from spot to Futures has been examined by Granger causality test. Johansen cointegration test also has been employed to investigate the long-run relationship between two markets. The result indicates that there is exist a long-run relationship between two markets. Further, Vector Error Correlation Model has been conducted to explore the short-run and long-run dynamics and price movements in two markets. VECM only indicates that there exists a long-run causality relationship running from spot market to Futures market and just spot market makes adjustments to obtain the long-run equilibrium. That meaning spot market leads Futures market in both the short-run and long-run. In the short-run, both Spot and Futures market is not affected by its past values. The Impulse Response Function and Variance Decomposition support the dominant role of Spot market than Futures market.

In conclusion, the main result of this paper is spot market lead Futures market in both of short-run and long-run. This is consist of previous papers like Zakaria \& Shamsuddin (2012), Tripathy (2014). They also investigated this relationship in an emerging economy like Vietnam. As a result of this paper, investors can use news and information from Spot market to predict Futures market. Therefore, they can improve their portfolio performance and also minimize the risk by building efficient strategies in hedging and speculating on Futures markets. Since this paper has given an overview of Spot and Futures market, regulators can rely on this research to come up with better policies to help stabilize the market and reduce risks for investors. At the same time, suitable policies can develop Futures market.

One of the limitations of this study just concentrates on VN30F1M and use daily closing price. The result may be different. Therefore, we suggest further research should use intraday price and concentrate on all of Futures contract, namely VN30F1M, VN30F2M, VN30F1Q, and VN30F2Q. Besides, to increase the accuracy of results, further research may add dummy variables for break-time between trading sessions. Instead of using VECM model, this relationship can also be explored by utilizing Bivariate GARCH model.

Because of our limit knowledge, this paper has inevitable errors. We are hopeful to receive ideas from all readers. 


\section{References}

Brooks, C., Rew, A. G., \& Ritson, S. (2001). A trading strategy based on the lead-lag relationship between the spot index and futures contract for the FTSE 100, 17, 31-44.

Chan, K. (1992). A Further Analysis of the Lead-Lag Relationship between the Cash Market and Stock Index Futures Market.

Chan, K., Chan, K. C., \& Karolyi, A. (1991). Intraday Volatility in the Stock Index and Stock Index Futures Markets.

Cheung, Y.-W., \& Lilian, K. N. (1990). The Dynamics of S\&P 500 Index and S\&P 500 Futures Intraday Price Volatilities.

ECONOMETRIC WITH APPLICATIONS: Johansen Cointegration Test with EViews. (n.d.). Retrieved December 4, 2019, from http://rizaudinsahlan.blogspot.com/2017/09/johansen-cointegration-test-with-eviews_93.html

Floros, C., \& Vougas, D. V. (2007). Lead-Lag Relationship between Futures and Spot Markets in Greece: 1999 2001. International Journal of Finance and Economics, 7(7), 168-174.

Granger Causality Test - an overview | ScienceDirect Topics. (n.d.). Retrieved December 4, 2019, from https://www.sciencedirect.com/topics/social-sciences/granger-causality-test

Iihara, Y., Kato, K., \& Tokunaga, T. (1996). Intraday Return Dynamics Between The Cash and The Futures Markets in Japan.

Judge, A., \& Reancharoen, T. (2014). An empirical examination of the lead-lag relationship between spot and futures markets: Evidence from Thailand. Pacific Basin Finance Journal, 29, 335-358. https://doi.org/10.1016/j.pacfin.2014.05.003

Kawaller, I. G., Koch, P. D., \& Koch, T. W. (1987). The Temporal Price Relationship between $S$ \& P 500 Futures and the $S \& P 500$ Index. (December).

Min, J. A. E. H., \& Najand, M. (1999). A F urther I nvestigation of the L ead - L ag R elationship between the $S$ pot $M$ arket and $S$ tock I ndex F utures: E arly E vidence from Korea, 19(2), 217-232.

Qin, R. Y., \& Heo, J. H. (2017). The Lead-Lag Relationship between Volatility Index Futures and Spot in the Korean Stock Market. Journal of International Trade \& Commerce, 13(4), 139-159.

Ren, F., Ji, S. D., Cai, M. L., Li, S. P., \& Jiang, X. F. (2019). Dynamic lead-lag relationship between stock indices and their derivatives: A comparative study between Chinese mainland, Hong Kong and US stock markets. Physica A: Statistical mechanics and Its applications, 513, 709-723.

Roope, M., \& Zurbruegg, R. (2002). Discovery Process between the Singapore Exchange and Taiwan Futures Exchange, 22(3), 219-240.

The University of Southamption, Faculty of Business, L., \& A. (2012, June). An empirical study of lead-lag relationship between spot and futures markets in three developing South East Asian countries, Malaysia, Thailand and Singapore, 7, 1-25.

Tripathy, N. (2014). Lead-Lag Relationship Between Spot and Future Market: Evidence From Indian Derivative Market. Academy of Taiwan Business Management Review, 10(3), 118-128.

Zakaria, Z., \& Shamsuddin, S. (2012). Relationship between stock futures index and cash prices index: empirical evidence based on Malaysia data. Journal of Business Studies Quarterly, 4(2), 103-112. 


\section{Appendix A}

\section{VECM Result}

Vector Error Correction Estimates

Date: 12/11/19 Time: 18:59

Sample (adjusted): 8/29/2017 11/29/2019

Included observations: 564 after adjustments

Standard errors in ( ) \& t-statistics in [ ]

\begin{tabular}{|c|c|c|}
\hline Cointegrating Eq: & CointEq1 & \\
\hline FUTURES(-1) & 1.000000 & \\
\hline \multirow[t]{3}{*}{ SPOT(-1) } & -1.050553 & \\
\hline & $(0.02294)$ & \\
\hline & {$[-45.7968]$} & \\
\hline $\mathrm{C}$ & -0.001747 & \\
\hline Error Correction: & D(FUTURES) & $\mathrm{D}(\mathrm{SPOT})$ \\
\hline \multirow[t]{3}{*}{ CointEq1 } & -1.558939 & 0.359366 \\
\hline & $(0.36730)$ & $(0.32292)$ \\
\hline & {$[-4.24430]$} & [ 1.11288$]$ \\
\hline \multirow[t]{3}{*}{ D(FUTURES(-1)) } & 0.434001 & -0.210252 \\
\hline & $(0.32401)$ & $(0.28486)$ \\
\hline & [ 1.33946$]$ & {$[-0.73809]$} \\
\hline \multirow[t]{3}{*}{ D(FUTURES(-2)) } & 0.473754 & -0.021056 \\
\hline & $(0.27444)$ & $(0.24128)$ \\
\hline & [ 1.72625$]$ & {$[-0.08727]$} \\
\hline \multirow[t]{3}{*}{ D(FUTURES(-3)) } & 0.244055 & -0.110234 \\
\hline & $(0.22491)$ & $(0.19773)$ \\
\hline & [ 1.08512$]$ & {$[-0.55749]$} \\
\hline \multirow[t]{3}{*}{ D(FUTURES(-4)) } & 0.025861 & -0.137497 \\
\hline & $(0.17068)$ & $(0.15005)$ \\
\hline & [ 0.15152$]$ & {$[-0.91634]$} \\
\hline \multirow[t]{3}{*}{ D(FUTURES(-5)) } & -0.036095 & -0.081605 \\
\hline & $(0.10409)$ & $(0.09152)$ \\
\hline & {$[-0.34675]$} & {$[-0.89171]$} \\
\hline \multirow[t]{3}{*}{$\mathrm{D}($ SPOT $(-1))$} & -1.430103 & -0.623360 \\
\hline & $(0.34247)$ & $(0.30109)$ \\
\hline & {$[-4.17579]$} & {$[-2.07035]$} \\
\hline \multirow[t]{3}{*}{ D(SPOT(-2)) } & -1.102416 & -0.531236 \\
\hline & $(0.29520)$ & $(0.25953)$ \\
\hline & {$[-3.73449]$} & {$[-2.04695]$} \\
\hline
\end{tabular}




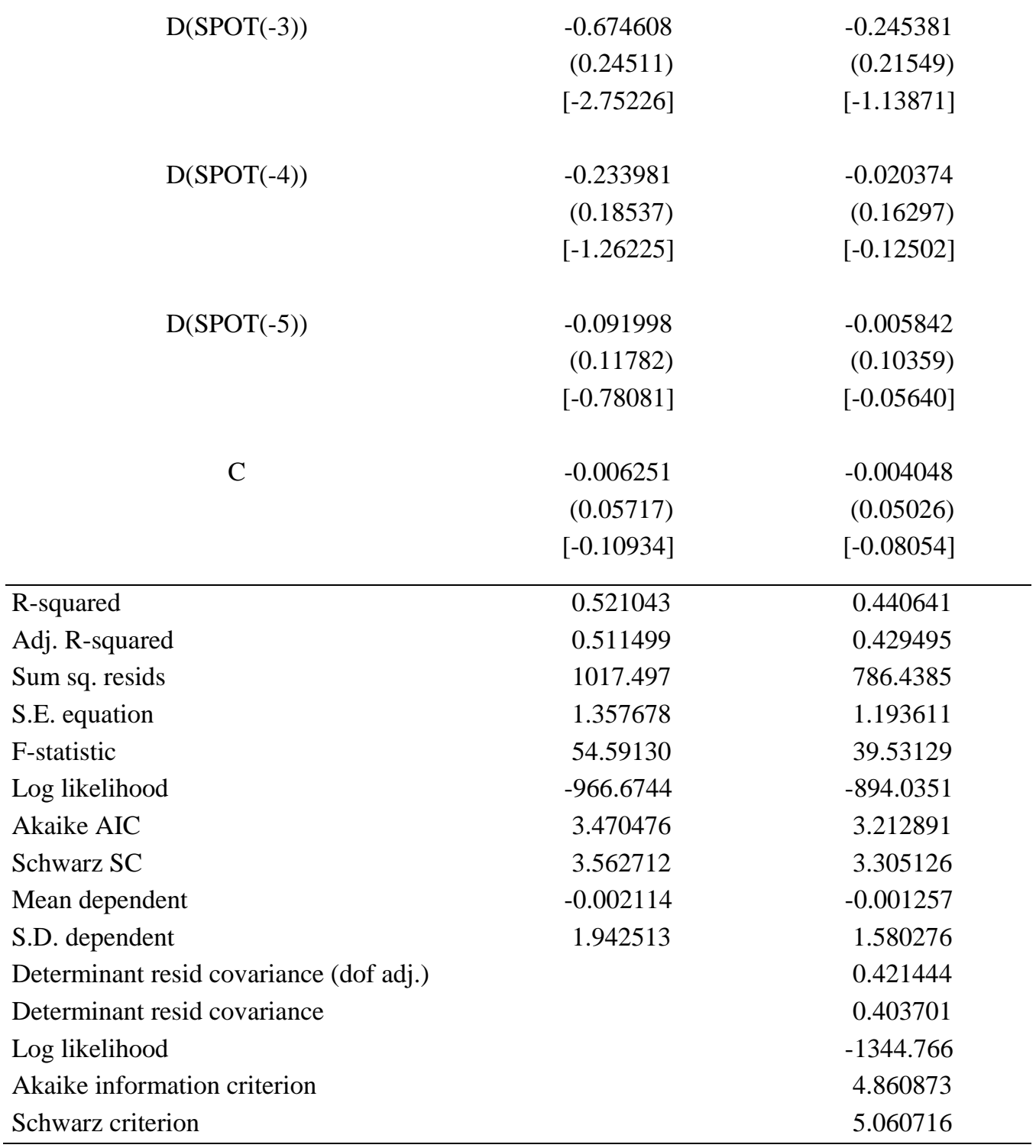

Note: *Significant at $1 \%$ level (critical Value: 2.58). (**) significant at 5\% level (Critical Value: 1.96). (***) significant at $10 \%$ level (Critical Value: 1.65) 


\section{Appendix B}

\section{Estimate Equation Where Futures Is Dependent Variable}

Dependent Variable: D(FUTURES)

Method: Least Squares

Date: 12/11/19 Time: 19:32

Sample (adjusted): 8/29/2017 11/29/2019

Included observations: 564 after adjustments

$\mathrm{D}($ FUTURES $)=\mathrm{C}(1) *\left(\right.$ FUTURES $(-1)-1.05055275935^{*} \mathrm{SPOT}(-1)-$

$0.00174736423327)+\mathrm{C}(2) * \mathrm{D}$ (FUTURES(-1)) + C(3)*D(FUTURES(-2))

$+\mathrm{C}(4) * \mathrm{D}($ FUTURES $(-3))+\mathrm{C}(5) * \mathrm{D}$ (FUTURES(-4)) + C(6)*D(FUTURES(

$-5))+\mathrm{C}(7) * \mathrm{D}(\mathrm{SPOT}(-1))+\mathrm{C}(8) * \mathrm{D}(\operatorname{SPOT}(-2))+\mathrm{C}(9) * \mathrm{D}(\mathrm{SPOT}(-3))+$ $\mathrm{C}(10) * \mathrm{D}(\operatorname{SPOT}(-4))+\mathrm{C}(11) * \mathrm{D}(\operatorname{SPOT}(-5))+\mathrm{C}(12)$

\begin{tabular}{rrrrr}
\hline & Coefficient & Std. Error & t-Statistic & Prob. \\
\hline C(1) & -1.558939 & 0.367302 & -4.244302 & 0.0000 \\
C(2) & 0.434001 & 0.324012 & 1.339457 & 0.1810 \\
$\mathrm{C}(3)$ & 0.473754 & 0.274442 & 1.726246 & 0.0849 \\
$\mathrm{C}(4)$ & 0.244055 & 0.224911 & 1.085115 & 0.2783 \\
$\mathrm{C}(5)$ & 0.025861 & 0.170675 & 0.151520 & 0.8796 \\
$\mathrm{C}(6)$ & -0.036095 & 0.104094 & -0.346749 & 0.7289 \\
$\mathrm{C}(7)$ & -1.430103 & 0.342475 & -4.175789 & 0.0000 \\
$\mathrm{C}(8)$ & -1.102416 & 0.295198 & -3.734495 & 0.0002 \\
$\mathrm{C}(9)$ & -0.674608 & 0.24511 & -2.752260 & 0.0061 \\
$\mathrm{C}(10)$ & -0.233981 & 0.185368 & -1.262247 & 0.2074 \\
$\mathrm{C}(11)$ & -0.091998 & 0.117823 & -0.780814 & 0.4352 \\
$\mathrm{C}(12)$ & -0.006251 & 0.057171 & -0.109336 & 0.9130 \\
\hline R-squared & 0.521043 & Mean dependent var & & -0.002114 \\
Adjusted R-squared & 0.511499 & S.D. dependent var & & 1.942513 \\
S.E. of regression & 1.357678 & Akaike info criterion & & 3.470476 \\
Sum squared resid & 1017.497 & Schwarz criterion & & 3.562712 \\
Log likelihood & -966.6744 & Hannan-Quinn criter. & & 3.506481 \\
F-statistic & 54.59130 & Durbin-Watson stat & & 2.027776 \\
Prob(F-statistic) & 0.000000 & & \\
\hline
\end{tabular}

\section{Copyrights}

Copyright for this article is retained by the author(s), with first publication rights granted to the journal.

This is an open-access article distributed under the terms and conditions of the Creative Commons Attribution license (http://creativecommons.org/licenses/by/4.0/). 